\title{
Part III: Reformers in medical education and practice
}

\author{
Martin A Entin MD FRCSC FACS
}

MA Entin. Part III: Reformers in medical education and practice. Can J Plast Surg 2002;10(3):103-108.

BACKGROUND: Part I (Can J Plast Surg 2000;8:25-29) established that standards of professional practice shift constantly. When a standard falls short of professional expectation, or when a physician becomes more concerned with financial gain than patient care, society needs the action of a reformer. Part II (Can J Plast Surg 2001;9:59-68) continued the study with the contribution of reformer John Hunter (1728-1793), followed with the contributions of seven other reformers, and concluded with Wilder Penfield (1891-1976). Part III extends this project through the greater part of the 20th century.

STUDY DESIGN: Reformers were scientists who were selected because they conformed to the definition of 'reformer'; namely, a person whose action restored, reshaped or changed the structure or ideology of medical practice.

RESULTS: This survey demonstrated that the reforms were accomplished by scientists who possessed critical judgement and analytical qualities that enabled them to influence the direction of medical education and practice.

CONCLUSION: Reforms have been achieved through intuitive leaps, alterations of conventional practice, painstaking research and administrative restructuring.

Key Words: Historical perspective; Medical reformers

\section{Partie III : Les réformateurs de la formation et de la pratique médicale}

HISTORIQUE : La partie I (Can J Plast Surg 2000;8:25-29) a établi que les normes de pratique professionnelle changent constamment. Lorsqu'une norme n'est pas assez sévère pour les attentes professionnelles ou qu'un médecin se préoccupe davantage des gains financiers que des soins aux patients, la société a besoin de l'action d'un réformateur. La partie II (Can J Plast Surg 2001;9:59-68) faisait état de la contribution du réformateur John Hunter (1728-1793), de celle de sept autres réformateurs, puis se terminait par l'apport de Wilder Penfield (1891-1976). Dans la partie III, ce projet se poursuit dans plus grande partie du $\mathrm{XX}^{\mathrm{e}}$ siècle. MÉTHODOLOGIE : Les scientifiques ont été choisis parce qu'ils adhéraient à la définition de "réformateur": une personne dont les actions ont permis de rétablir, de remodeler ou de modifier la structure ou l'idéologie d'une pratique médicale.

RÉSULTATS : Cette enquête démontre que les réformes ont été accomplies par des scientifiques qui, grâce à leur jugement critique et à leurs qualités analytiques, ont influencé l'orientation de la formation et de la pratique médicale.

CONCLUSION : Les réformes ont été réalisées par des bonds intuitifs, par des modifications à la pratique traditionnelle, par des recherches laborieuses et par des restructurations administratives.

Plastic and Reconstructive Surgery, Royal Victoria Hospital, Montreal, Quebec

Correspondence and reprints: Dr MA Entin, Royal Victoria Hospital, F 946-687 Pine Avenue West, Montreal, Quebec H3A 1A1.

Telephone 514-843-1468, fax 514-843-1440 
$\mathrm{T}$ he reformers selected for this series in the history of medicine were extraordinary individuals who not only altered the direction of medical research, but also reshaped medical philosophy. Their innovations effected profound changes in the theoretical and practical study of human medicine and disease. The account began with the iconoclastic Hippocrates, who totally dismissed the notion that disease was "a punishment by the gods", and supplanted it with the rational idea that disease was a natural phenomenon to be treated with natural remedies.

At the turn of the century, the increased demand for physicians and the concomitant accelerated training of this new corps of prospective doctors generated a lowering of standards at United States medical colleges. Flexner (1), who was sponsored by the Carnegie Foundation in 1908, published a report on the standards of education, including those of medical colleges. This resulted in a reformation of medical education in North America. Between World War I and World War II, research grew to such an extent that medical schools were encouraged to align themselves with universities, and a major part of the training of doctors was done at university hospitals. A period of growth that took place at the universities after the major wars was stimulated by economic prosperity, extension of research and the help of private and state philanthropy.

\section{FG BANTING AND HIS SEARCH FOR INSULIN}

Nicolas Paulescu (2), a Romanian scientist, discovered that an agent secreted by pancreatic acini could correct a diabetic condition caused by the inability of the liver to store sugar. Canadian surgeon FG Banting directed his research to isolating this agent, which was secreted directly into the bloodstream from the pancreatic islet cells. Banting thought that ligating the pancreatic duct in dogs would eliminate any secretion into the body. The excision of the pancreas created a diabetic state that he believed could be treated through insulin injection.

Diabetes was a condition of multifactorial nature (3). In the juvenile form, children and young adults, although born with healthy islet cell function, were still susceptible to viral infection. The antigen-antibody reaction destroyed the beta cells of the pancreas, thereby producing a diabetic condition (4). The term 'diabetes' applies to a heterogenous collection of disorders that is characterized by hyperglycemia and is without a common cause. Most diabetic conditions respond to insulin treatments (5).

Fred Banting was not a typical 'reformer' moved by an altruistic or missionary desire to put things right. He intended to practise surgery and received a part-time appointment as a demonstrator in surgery at the University of Western Ontario, London. One evening, while preparing a lecture, he chanced upon an article on pancreatic function in an issue of Surgery, Gynecology and Obstetrics. Inspired by the article, Banting spent the night pondering the problem of the cause of diabetes and jotted down an experimental procedure to isolate the internal secretion of the pancreas as a step in the treatment of diabetes. This prompted him to give up his practice in London and to devote himself full-time to research.

Banting knew that the active agent, insulin, was contained within the whole organ of the pancreas (6). He hoped that extracting the active agent from a dog's ligated pancreas and injecting it intravenously into a diabetic dog would control the diabetes. The difficulty was that injection of the solution obtained from the ligated pancreas did not always reduce the blood sugar. Professor J Macleod, head of the Department of Physiology at the University of Toronto, to whom Banting went for assistance, knew that the islet cells in a special part of the pancreas synthesize and discharge insulin into the blood stream. Insulin alleviates the diabetic state because it permits the transfer of glucose into cells of the body, where it can be used as a source of energy. Macleod understood the difficulties that Banting and his assistant, $\mathrm{CH}$ Best, were having with the unpredictability of their extract and he also realized that biochemist JB Collip from the University of Alberta, Edmonton, who happened to be visiting Toronto, could help Banting with the extract. However, he decided to give Banting and Best an opportunity to 'complete' their research project without assistance (7). In spite of the lack of encouraging results from the canine experiments, Banting was anxious to try the extract on patients with diabetes. On December 20, 1921, his friend and classmate, Joe Gilchrist, a chronic diabetic, was administered some extract orally - no positive result was detected. Neither Banting nor Best knew that insulin could not be given orally.

Ten days later, Banting was persuaded to present a paper at the American Physiological Society conference at Yale University, New Haven, Connecticut. He was not able to speak authoritatively about his research and was disappointed with his delivery. During the discussion period, Macleod tried to support Banting's presentation.

There was public pressure to try the pancreatic extract on diabetic patients. On January 11, 1922, Banting's pancreatic extract was injected into the buttock of Leonard Thompson, a 14 year-old boy with diabetes. The treatment was a failure - the boy developed a sterile abscess at the site of injection due to impurities (8).

Banting's original idea to use the extract from insulinproducing pancreatic islets of dogs to treat diabetes turned out to be more complicated than he initially imagined. His inexperience in conducting experiments, compounded by a lack of rigorous, disciplined procedure, resulted in the failure to produce a reliable extract. The experiments' procedures and documentation were shoddy and inconsistent, and lacked professionalism. Discouraged, Banting sought the assistance of Collip. The carefully documented "Discovery of Insulin" (9) by Michael Bliss offered a detailed analysis of the events and behaviour of the researchers, and also helped to understand and provided insight into the causes of Banting's research impasse. Bliss (9) described how the research advanced positively when Collip joined Banting and Best in November, 1921. The 'purification' process of Banting's pancreatic extract began 
in December, 1921. The unreliability of the amorphous extract from the degenerated pancreas of Banting's dogs necessitated a change in methodology. Collip switched to fresh beef pancreas as a source for the purified insulin. This was a more predictable and elegant source (10).

The several grievances that Banting voiced against Macleod and Collip at that time were amply described by Bliss (9). But tranquility and harmony ensued when Collip demonstrated that his purified extract restored glycogen formation in the liver and abolished ketosis. Administration of the new extract, which became available after January 19, 1922, produced startling results. When 14-yearold Leonard Thompson was given the second injection of insulin, his blood sugar dropped from .520 units to .120 units, a dramatic clinical improvement. Collip's ingenious method involved the use of alcohol in different concentrations. Ninety per cent alcohol precipitated out the active principle of insulin, which made it suitable for direct administration in diabetic patients (11). Emboldened by this success, the group submitted an article to the Canadian Medical Association Journal entitled, "Pancreatic Extract in the Treatment of Diabetes Mellitus". A few weeks later, on May 3, 1922, Macleod read a paper to a group of diabetes experts in Washington, District of Columbia. The representative of the Nobel Prize Committee came to the University of Toronto. Apparently, he did not wish to lose any time in searching for scientific evidence. The committee decided to give the Nobel Prize for Physiology and Medicine for 1923 to F Banting and J Macleod. Many considered this to be one of the greatest achievements in contemporary medicine (9). Banting and Macleod unofficially shared the money and prize with Best and Collip.

\section{ADRENAL CORTICAL HORMONES AND THEIR CLINICAL APPLICATIONS}

American biochemist Edward Calvin Kendall was born in Connecticut in 1886. He graduated from Columbia University (New York, New York), where he trained as a physiologist and chemist and later became Professor of Biochemistry at the Mayo Clinic, University of Minnesota, Rochester. His identification of thyroxin, an active principle of the thyroid gland, facilitated the correction of deficiencies in thyroid gland secretion (12). Later, he became interested in the hormones of the adrenal cortex. In association with other researchers, six biological active agents (A, B, C, D, E and F) were discovered (13). In tandem with Kendall's research, Dr Roger Reinecke, an associate of Dr Kendall, devised a bioassay for corticoid hormones that influenced carbohydrate metabolism, a significant connection.

In 1941, a conference on the adrenal cortex was held at Yale University. In response to a widely held notion that German scientists were pulling ahead of the United States in this area, several research committees were formed. One committee, organized to do research on Compound E, was headed by the chair of the chemistry group, Dr William Clark. Apart from this, very little interest was shown in this agent of the adrenal cortex. While research on Compound E was being undertaken, Philip Hench of the Mayo Clinic was engaged in locating and isolating a substance that could control rheumatoid arthritis (14).

Hench noted that patients who suffered from rheumatoid arthritis reported an improvement in their condition after they had developed jaundice. A similar effect was observed in pregnant patients with rheumatoid arthritis, although this was not constant. Hench then attempted to induce jaundice in his arthritic patients, but was unsuccessful. The organic compound lactophenin was suggested as an inducement, but it was only partially successful. Only three of his patients developed jaundice with the positive side effect of relief from arthritic pain. No further progress was made (15).

In that same year, Kendall and Hench arranged a conference at the Mayo Clinic to discuss the needs of patients with arthritis. Hench encouraged the use of Compound E, and they both agreed to test it in the treatment of rheumatoid arthritis. However, it took eight years for them to put it to empirical trial.

On August 1, 1948, Kendall happened to meet Hench, who again broached the subject of Compound E. Several days later, Kendall received an urgent call from Hench, who recounted the care of his patient, Mrs G, who, despite lactophenin treatments, continued to have pain from arthritis (15). Hench then tried Compound E, which, suspended in sodium chloride, was administered daily in $100 \mathrm{mg}$ doses through intramuscular injection (15). Mrs G showed marked improvement after a week of injections. Dr Kendall was quick to realize that there were three million patients in the United States who were stricken with rheumatoid arthritis, but only a scant amount of Compound $\mathrm{E}$ was available for treatment. During the next two months, several patients were treated and more than 1500 injections were administered without attendant infection. It was later discovered that Compound $\mathrm{E}$ and its acetate, ester, were effective in liquid form. However, some undesirable side effects were noted - particularly, increases in blood pressure and obesity. Further side effects of inflammation and hypersensitivity in the arthritic areas were suppressed through other corticosteroids (15).

In 1949, Hench suggested the name 'cortisone' for Compound $\mathrm{E}$. The manufacture of cortisone for commercial use was undertaken by Merck and Company (USA). Because it was an accepted policy at the Mayo Clinic that the staff not profit from the work done in its laboratories, Kendall did not personally benefit from his research (15).

Cortisone, extracted from bile acid through a process that required more than 30 different reactions, was an achievement that Kendall considered to be a landmark in the history of industrial chemistry. Initiated by Hench, the clinical effect of cortisone on rheumatoid arthritis was dramatic (16). Countless people who were suffering with this debilitating illness found some measure of relief through cortisone treatment.

In 1950, the Nobel Prize was awarded to EC Kendall, PS Hench and Taddeus Reichstein for their research on adre- 
nal cortex hormones, their structures and biological activity. Reichstein had been working simultaneously on the same problem in Basel, Switzerland - not an uncommon occurrence in the history of science (17).

\section{TRANSPLANTATION OF TISSUE FROM ONE INDIVIDUAL TO ANOTHER}

The concept that every individual represents a unique 'self' goes back to antiquity, when attempts to replace destroyed or severed parts of the anatomy of one individual by transplanting a corresponding part from a nonrelated individual always resulted in rejection.

In the first half of the 20th century, three teams of reformers were working in different parts of the world trying to understand and to correct the phenomenon of 'rejection'. Each group's contribution helped to enhance the transfer of tissues and organs and each group was rewarded with the Nobel prize for its achievements. This first group comprised the Oxford team of FM Burnet and PB Medawar. They were contemplating and reworking the established concept of 'self', investigating the behaviour of unborn embryos in an animal model and the concepts of 'tolerance' and 'rejection'. Based on their research and observations, they established the following sequence of progression, beginning with unborn embryos and proceeding into adulthood:

1. There is no evidence that qualities of 'self' are present in unborn embryos: tissue can be transplanted successfully from one litter mate to another (18).

2. Embryos can acquire tolerance to grafted foreign tissue. This tolerance is for the life of the individual who will accept tissue from the donor (19).

3. Although fraternal twins don't have tolerance for each other's tissue, if they develop cross circulation during gestation, they acquire tolerance to each other (20).

4. Identical twins tolerate exchange of tissue grafts. This procedure is accepted as legal proof of identity. (Refer to McIndoe's testimony in the case of mistaken exchange of Italian newborn twins [21]).

5. Inbreeding will increase the relative chances of success of skin grafting between litter mates.

6. Rejection reaction is based on an individual immunological pattern of 'self' (22).

a) it does not depend on the formation of antibodies, but rather on the "difference on histocompatibility".

b) rejection is a function of small white blood cells of the recipient.

7. Blood transfusion is not 'rejected' because red blood cells have no nuclei, which are the source of the antigen protein.

Burnet and Medawar established the reaction of rejection between nonrelated donors, but they also pointed out that there had been positive, successful results in the exchange of tissues and organs between identical twins.

Joe Murray and his associates JP Merrill and JH Harrison comprised the second group, and they worked at Harvard University, Cambridge, Massachusetts (23). They possessed extensive experience in experimental renal homografts in animals. After Medawar showed that failure in homotransplantation was an immunological response, and tissue transfer succeeded only in consanguineous individuals (identical twins), Murray and his coworkers were the first to transplant a kidney from one human identical twin to the other. They noted that cortisone prolonged the partial survival of homografts in nonrelated individuals, but that these results were not always reproducible (24).

The third team, chemists George H Hitchings, Jr and his associate Gertrude Elion, worked for the Burroughs Welcome Pharmaceutical Company (USA), and were engaged in the development of antiviral, antibacterial and anticancer drugs (25). Dr Hitchings, who knew that nucleic acid was common in all living cells, noted that subtle chemical changes in the structure of the nucleic acid prevented the growth of various types of cells. Small alterations in the structural nature of nucleic acid, which would be harmful to organisms, are undetected by those organisms, and cause their death only after they ingest them. Hitchings summarized the principle of nucleic acid cell alteration: "We change the donuts into 'rubber donuts' but the cells don't notice the change. They swallow the donuts and kill themselves" (26).

The collaborative research of Hitchings and Elion resulted in advances to control the Herpes and AIDS viruses. They also discovered azathioprine (Imuran, Glaxo Wellcome, Canada), a substance that suppresses the immunological responses, thus overcoming an obstacle in the homotransplantation of tissues. Hitchings and Elion (27) shared the 1988 Nobel Prize for Medicine and Physiology with British pharmacologist Sir James Black (28). Imuran increased the practicability for human organ transplantation. Other substances have since been discovered; cyclosporin is one of the newer immunosuppressive drugs (29).

\section{JOE MURRAY AND HIS GROUP}

Joe Murray's team was greatly encouraged by the discovery of Imuran, which revolutionized the practice of human organ transplantation. They performed one of the first successful kidney transplants between nonrelated human individuals. Appropriately, Murray and his collaborators received the Nobel Prize for their endeavours (30). Thanks to them, organ transplants are now a commonplace surgical procedure, although the more complicated heart and liver transplants could only be attempted after the development of more specialized technology. 


\section{INTERNATIONAL TESTS OF CONSANGUINUITY}

Sometime during World War II, red-haired twin sons of a local butcher and a dark-haired son of a local plumber were delivered at the hospital in Rome, Italy within a couple days of each other. One of the red-haired infants was inadvertently switched for the dark-haired infant at the time of discharge five days later. Years later, when the children were attending the same school, it was noted that one of the twins resembled more the plumber's son. Suspicion of infidelity began to undermine the social structure of the tradesmen's closeknit community.

Before the matter was taken up in Roman court, a forensic lawyer suggested that only reciprocal exchange of skin between the children could establish which of the three were truly twins.

Sir Archibald McIndoe, the renowned British plastic surgeon who became famous during World War II for salvaging the lives of Royal Air Force pilots, was invited to Rome to carry out the exchange of skin grafts among the three boys. Careful preparation was required and the operations were carried out under sterile conditions by Dr McIndoe in the local hospital. Within one week, the doctors observed that the grafts survived only in each of the red-haired boys (21). Notwithstanding the decision of the Roman court to restore the children to their respective parents, neither family surrendered the children that they had grown to love over the years.

\section{REFORMERS OF THE TRANSFER OF INFORMATION IN LIVING MATTER}

In 1866, George Mendel postulated that genes control the inheritance of physical traits in all living beings. At the turn of the century, genes were found in the chromosomal structure of the cell nucleus.

Genetic research mushroomed when it was discovered that one of the nucleic acids, DNA, was the building block of genetic structure. The three recipients of the Nobel Prize, Francis Crick, J Watson and Maurice Wilkins, came to the prize from different directions.

Crick, the English molecular biologist, began his preparation by learning x-ray diffraction at Strangeways Research Laboratories in Cambridge, United Kingdom, in 1947. He joined the Cavendish Laboratory, United Kingdom, in 1949 under Max Perutz, whose interests were the molecular structure of protein and the genetic coding of amino acid sequencing (31).

When James Watson, the American biologist, joined the Medical Research Council Laboratory in Cambridge, United Kingdom, Perutz and Crick were engaged in deciphering the structure of protein. Watson fits the definition of 'reformer' because his action helped to reshape the structure and ideology of medical science - Watson persuaded the researchers at Cambridge that the study of the structure of genes had priority because genes determined the protein structure. Subsequently, Watson and Crick collaborated in the discovery of the double helix structure of DNA and were awarded the Nobel Prize (32).

Physicist Wilkins moved from Saint Andrews, Scotland, to Kings College, London, United Kingdom. Having examined some $\mathrm{x}$-ray diffraction patterns of DNA, he took them to Raymond Gosling, who obtained encouraging diffraction patterns as well. When Crick and Watson saw these patterns at Cambridge they were inspired to design a suitable molecular model and eventually discovered the double helix. The helical arrangement of the constituent collagen fibres of bones and ligaments was well known to molecular biologists. Electron microscopy had revealed that these substances possess regular cross-structures. They represented a helical arrangement of basic protofibrils, each of which was composed of three polypeptide chains wound around each other (33). Moreover, Watson and Crick had some notion of the possible structure of nucleic acid from the original diffraction studies of their colleagues (34). The complex structure of sequential amino acid arrangements interlaced with base components was realized or visualized in the double helix model (35). This specific architectural sequence best represented the life-forming regenerative process.

In accepting his Nobel prize, Crick emphasized the biological importance of the work achieved by his team (36). He believed that nucleic acid carries all genetic information. Twenty different kinds of amino acids are commonly found in protein and four main kinds of base occur in nucleic acid. Crick further stated that DNA controls protein synthesis directly (37). The base sequence of DNA is copied onto RNA, and this special RNA then acts as a genetic messenger and directs the actual process of joining the amino acids into polypeptide chains. Crick continued (38):

The code of different organisms is thought to be similar if not identical. Evidence of this similarity will be equal evidence of the fundamental unity of all living things... This means one can expect within a few years, not only detailed knowledge of the genetic code, but also experimental means of altering and coding information to produce variations of polypeptide structures that will direct synthesis of new laboratory design proteins as well as old ones...At the same time, we shall gain a better understanding of the interaction of heredity and environment, of mutations and their consequences for enzyme synthesis, and, perhaps, even new insights into the origin of life.

\section{CONCLUSIONS}

What does this kaleidoscopic survey of reformers reveal? It reveals that all reformers possess acute critical judgement: what is false or faulty is rejected while standards of research and enquiry are either restored or elevated to a degree far in advance of accepted measured progression. This is achieved either through a leap of knowledge or through the institution of public health reforms.

A visionary, dedicated physician from 2500 years ago created a professional guild to distinguish doctors from shamans and magicians in his society. From that time to the 
present, each member of the guild swore to be loyal to his teachers and to his patients, forging a chain of unbreakable secular bonds.

Judging from the numerous breaches, broken commitments, and even falsifications, the Hippocratic Oath has recently become little more than a 'lip service', traditional ceremony that managed care contracts demand from subscribing doctors.

\section{REFERENCES}

1. Flexner A. Medical Education in the United States and Canada: A Report to the Carnegie Foundation for the Advancement of Teaching. New York: The Carnegie Foundation, 1920. (Bulletin No.4)

2. Paulescu NC. Demonstration of presence in pancreas of anti-diabetic hormone. Arch Int Physiol 1921;17:85-9.

3. Bloom A. Nature of diabetes. J Roy Soc Med 1978;71:170-9.

4. Bloom A, Hayes TM, Gamble DR. Juvenile diabetes. Br Med J 1975;3:580-3.

5. Barron M. The relation of the islets of Langerhans to diabetes with special reference to cases of pancreatic lithiasis. Surg Gynecol Obstet 1920;31:437-48.

6. Banting FG, Best $\mathrm{CH}$. Internal secretion of pancreas. J Lab Clin Med 1922;7:251-326.

7. Bliss M. Banting's, Best's, and Collip's accounts of the discovery of insulin. Bull Hist Med 1982;56:554-68.

8. Banting FG, Campbell WB, Fletcher AA. An insulin treatment of diabetic mellitus. J Metab Res 1922:547-604.

9. Bliss M. Discovery of Insulin. Toronto: McClelland \& Stewart, 1982.

10. Bliss M, Collip JB. A forgotten member of the insulin team. In: Mitchison W, McGinnis JD, eds. Essays in the History of Canadian Medicine. Toronto: McClelland and Stewart, 1988:110-25.

11. Stephenson L. Sir Frederick Banting. Toronto: Ryerson Press, 1946.

12. Mason HL, McKenzie BF, Kendall EC. Glutomyocystenyl-glycine compound. J Biol Chem 1930;84:657-75.

13. Kendall EC. The identification of a substance which possesses the qualitative action of cortin. J Biol Chem 1936;116:267-76.

14. Hench PS, Kendall EC. Effect of cortisone, attitude and pituitary ACTH on rheumatoid arthritis, rheumatic fever and certain other conditions. Arch Intern Med 1950;85:545-666.

15. Kendall EC. Cortisone. New York: Charles Scribner, 1971.

16. Kyle RA, Shampo MA. Philip S Hench. JAMA 1980;244:39.

17. Raju TN. The Nobel Chronicles. 1950: Edward Calvin Kendall (1886-1972); Philip Showalter Hench (1896-1965); and Tadeus Reichstein (1897-1996). Lancet 1999;353:1370.

18. Owen RD. Immunogenetic consequence of vascular anastomosis between bovine twins. Science 1945;102:400.

19. Owen RD. Acquired tolerance. Proc Roy Soc 1956;146:1956-8.

20. Billingham RE, Brent L, Medawar PB. Actively acquired tolerance of foreign cells. Nature 1953;172:603.
Is the Hippocratic Oath to be discarded as an impractical, unachievable whim? Or have we come to a new stage in the evolution of medical education and practice that demands of us not only required alternative diagnostic procedures and methods of treatment, but also a new relationship with patients that evokes a different form of dedication and a new oath? These are crucial questions that have yet to be answered or resolved.

21. McIndoe A, Franceschetti A. Reciprocal skin homografts in medical legal case of familial identification of exchanged identical twins. Br J Plast Surg 1953;2:283.

22. Gibson T, Medawar PB. The fate of homografts in man. J Anat 1943;77:299.

22. Murray JE, Merrill JP, Harrison JH. Kidney transplantation between seven pairs of identical twins. Ann Surg 1958;148:343.

24. Murray JE. Organ transplants: A type of reconstructive surgery. Can J Sur 1965;8:340-50.

25. Korelitz BI, Prisent DH. History of immunosuppressive drugs in the treatment of inflammatory bowel disease. Mt Sinai J Med 1996;63:191-201.

26. Hitchings GH. Award of Leukemia Society of American Med/751, 45681. Bibl Haemotol 1970;36:XXI-XXII.

27. Elion GB. Pharmacology of azathioprine. Ann NY Acad Sci 1993;685:400-7.

28. Raju TN. The Nobel Chronicles. 1960: Sir Frank Macfarlance Burnet (1899-1985) and Sir Peter Brian Medawar (1915-87). Lancet 1999;353:2253.

29. Special Issue in Memory of Gertrude B. Elion. Nucleosides Nucleotides Nucleic Acid 2000;19:1-513.

30. Raju TN. The Nobel Chronicles. 1990: Joseph Edward Murray (b 1919) and E. Donnall Thomas (b 1920). Lancet 2000;355:1282.

31. Perutz MF. Before the double helix. Gene 1993;135:9-13.

32. Watson J. The Double Helix. New York: Scribners Classics, 1968.

33. Reed R. The archistructure of collagen fibre. In: Keech M, Delafresnaye JF, Wood GC, eds. Connective Tissue. Oxford: Blackwell Scientific Publications, 1957.

34. Watson JD, Crick FHC. Molecular structure of nucleic acid: A structure for deoxyribose nucleic acid. Nature 1953;171:737-8.

35. Crick F. Crick looks Back on DNA. Science 1979;206:667.

36. Raju TN. The Nobel Chronicles. 1962: Frances Harry Compton Crick (b 1916); James Dewey Watson (b 1928); Maurice Hugh Frederick Wilkins (b 1916). Lancet 1999;354:171.

37. Kyle RA, Shampo MA. Wilkins, Crick and Watson: Nobel prize for work on the structure of DNA. Mayo Clin Proc 1998;73:36.

38. Sourkes TL. Nobel Prize Winners in Medicine and Physiology, 19011965. London: Adelard Schuman, 1966. 